\title{
NEGRO EMPLOYMENT IN FINANCE
}

A Study of Racial Policies in Banking and Insurance 


\section{INDUSTRIAL RESEARCH LNIT \\ WHARTON SCHOOL OF FINANCE AND COMMERCE UNIVERSITY OF PENNSYLVANIA}

Founded in 1921 as a separate Wharton Department, the Industrial Research Unit has a long record of publication and research in the labor market, productivity, union relations, and business report fields. Major Industrial Research Unit studies are published as research projects are completed. Advanced research reports are issued as appropriate in a general or special series.

Major Industrial Research Unit Studies

(Available from the University of Pennsylvania Press or the Industrial Research Unit)

No. 40 Gladys L. Palmer, et al., The Reluctant Job Changer. 1962.

No. 41 George M. Parks, The Economics of Carpeting and Resilient Flooring: An Evaluation and Comparison. 1966.

No. 42 Michael H. Moskow, Teachers and Linions: The Applicability of Bargaining to Public Education. 1966.

No. 43 F. Marion Fletcher, Market Restraints in the Retail Drug Industry. 1967.

No. 44 Herbert R. Northrup and Gordon R. Storholm, Restrictive Labor Practices in the Supermarket Industry. 1967.

No. 45 William N. Chernish, Coalition Bargaining: A Study of Union Tactics and Public Policy. 1969.

No. 46 Herbert R. Northrup, Richard L. Rowan, et al., Negro Employment in Basic Industry: A Study of Racial Policies in Six Industries. Studies of Negro Employment, Vol. I. 1970.

No. 47 Armand J. Thieblot, Jr., and Linda P. Fletcher, Negro Employment in Finance: A Study of Racial Policies in Banking and Insurance. Studies of Negro Employment, Vol. II. 1970.

No. 48 Bernard E. Anderson, Negro Employment in Public Utilitics: A Study of the Racial Policies of the Electric Power, Gas, and Telcphone Industry. Studies of Negro Employment, Vol. III. 1970.

No. 49 Herbert R. Northrup, et al., Negro Employment in Southern Indiustry: A Study of the Racial Policies of the Paper, Lumber, Tobacco, Bituminous Coal, and Textile Industries. Studies of Negro Employment, Vol. IV. 1970.

Nos. 1-39 Available from Kraus Reprint Co., 16 East 46th St., New York, N.Y. 10017. 


\title{
NEGRO EMPLOYMENT IN FINANCE
}

A Study of Racial Policies in Banking and Insurance

(Volume II-Studies of Negro Employment)

\author{
by \\ Armand J. Thieblot, JR. \\ Assistant Professor of Management \\ Collcge of Business and Public Administration \\ University of Maryland \\ and \\ Linda Pickthorne Fletcher \\ Associate Professor of Insurance \\ College of Business Administration \\ Louisiana State University
}

With the assistance of

MARJORIE C. DENISON

and

ELSA KLEMP

INDUSTRIAL RESEARCH UNIT

Wharton School of Finance and Commerce

University of Pennsylvania 
Copyright (C) 1970 by the Trustees of the University of Pennsylvania Library of Congress Catalog Card Number 79-128560

ISBN: $0-8122-7622-1$ 